\title{
DE HOMBRES Y OTRAS ALIMAÑAS EN LOS RETRATOS LITERARIOS DE JOSÉ MARÍA VARGAS VILA
}

\author{
POR \\ María A. SALGado \\ The University of North Carolina at Chapel Hill
}

José María Vargas Vila (1860-1933), conocido como El Divino, vivió su vida y escribió su obra política y literaria en función de (auto-proclamado) líder de la ideología liberal. Para el escritor, su apasionada lucha contra el conservadurismo, o cualquier otro tipo de tiranía u opresión, constituía la esencia de su identidad, según lo articula él mismo en uno de sus retratos literarios, donde se duele de que su voluntariosa defensa de la libertad moriría con él, al no haber ganado un emulador:

[...] yo, que tengo tantos imitadores en / literatura, no tengo imitadores en política; / ¿a qué imitar mis libros y no imitar mi actitud / heroica ante el Despotismo?

eso sería glorioso;

yo, veo aparecer a diario, jóvenes llamados a / igualar y aún a superar mi literatura; pero, ¿dónde está aquel que ha de sucederme / políticamente el revolucionario inabordable, el Panfletario inapaciguable, ¿dónde está?

se tiene miedo al insulto, al destierro, a la miseria, a la calumnia, a todos estos claveles rojos, que crecen sobre mi frente y que son mi gloria;

he ahí el por qué de mis tristezas;

yo no amo mi obra literaria, sino porque es una parte, o mejor dicho, una forma de mi obra política; / fuera de lo que contiene de ideas yo no le tengo grande amor;

es verdad que en mi Vida, el Arte y la Libertad, / se han unido indisolublemente; pero, yo no amo mi vida, sino por la parte que en ella he consagrado a la Libertad, que ha sido toda, porque mi Arte, no ha sido sino la más bella rosa de mi pensamiento, ofrecida por mi mano, a esa diosa sin creyentes...

¿qué me puede importar a mí, que mi literatura / tenga sucesores, si el sucesor de mis cóleras / de mis odios, de mis anatemas, el Gran Libelista contra la Tiranía, no aparece? (Lises 243)

Sus cóleras, sus odios, sus anatemas de Gran Libelista contra la Tiranía son en efecto lo que con mayor precisión se refleja en los numerosos retratos de figuras políticas y de hombres de letras, que escribió en su exaltado estilo de "panfletario inapaciguado", 
y con los que contribuyó a difundir su proyecto político liberal. ${ }^{1}$ Vale aclarar, sin embargo, que no todas sus animosidades y anatemas se proyectan de manera negativa; al contrario, muchos de sus retratos, tales como los de sus correligionarios e intelectuales, pregonan su admiración por las virtudes que faltan a los tiranos. No obstante, ambos tipos de retrato son, en esencia, "panfletarios" y ambos emplean con gran éxito una de las armas literarias más exitosas para escarnecer a los que no coinciden con sus ideas o exaltar a los que las comparten: la animalización. ${ }^{2}$ El parque zoológico de Vargas Vila es vasto y sorprendentemente imaginativo; identificarlo, estudiando su variedad, sus estrategias, su simbolismo y su significación es la tarea que llevo a cabo en este ensayo.

En literatura, la animalización ha formado parte de la caracterización humorística o caricaturesca de los seres humanos desde los ya lejanos días en que Teofrasto hizo uso de ella para trazar algunos de sus mordaces Caracteres o Caracteres morales. No es insólito pues que Vargas Vila se haya apropiado de tan importante artilugio; lo insólito para el lector viene a ser la imaginativa y personal distorsión que su pluma panfletaria inflige en la persona y personalidad de los hombres que retrata para acomodarlos a su visión, refractándolos con frecuencia a través de las connotaciones positivas o negativas

1 El retrato literario se remonta a los orígenes de la literatura occidental. No obstante, fue reinventado a fines del siglo XIX por los modernistas, quienes escribieron retratos y autorretratos en prosa o en verso de relativa brevedad en los que plasmaron de manera iconográfica, es decir, subjetiva, momentánea y unilateral, aunque no necesariamente visual, la esencia (genio y figura) propia o ajena. Dichos retratos identifican de manera explícita al personaje retratado, estableciendo un pacto con el lector que facilita la lectura biográfica.

A través de los años, Vargas Vila fue recogiendo en libros la cuantiosa producción de retratos que había publicado en revistas y periódicos de varios países. Sus títulos finales serían, Los Providenciales (1892), A la hora del crepúsculo (1900?), Los Divinos y los Humanos (1904), Los Césares de la decadencia (1907), En las cimas (1915?), Pretéritas (1915?), Sombras de águilas (1916?), De sus lises y de sus rosas (1920) e Históricas y Políticas (1930?). La aparente individualidad de estos títulos oscurece que en estos libros baraja y con frecuencia repite los más de setenta retratos que incluye. Barajar y repetir los mismos retratos (de los que sólo infrecuentemente escribe versiones alternas) es desconcertante tanto para establecer la cronología de su obra como la evolución de su pensamiento. Esto sucede a pesar de que el propio Vargas Vila ha reconocido la subjetividad así como lo momentáneo y parcial de su escritura, apuntando a que sus retratos reflejan su manera de sentir en tiempos y espacios determinados, y han de leerse dentro de su contexto histórico: "el tiempo, como el fuego, purifica cuanto toca; / el tiempo es un crisol; / en él, se funden nuestras pasiones; / nuevos estados de alma; / nuevas maneras de sensibilidad surgen en nosotros; / agotadas las viejas fuentes de la Emoción; / o transformadas en otras; / cambian nuestros sentires; / y nuestros decires con ellos; / penoso trabajo de reconstrucción, es éste de poner en pie un estado de alma pretérito y de muchos años ya difunto; / tanto valdría tratar de reconstruir un pedazo de cielo, con sus nubes ya desaparecidas y, las estrellas extintas; / tal habríame de suceder si ensayara de resucitar en mi los estados de alma sucesivos en que mis libros fueron escritos" (énfasis mío); en prefacio de Parias, VII.

2 El lenguaje panfletario, eminentemente inflamatorio, de Vargas Vila, ha sido estudiado por Consuelo Triviño en "Vargas Vila o el arte de injuriar".

Revista Iberoamericana, Vol. LXXXI, Núm. 252, Julio-Septiembre 2015, $741-756$ ISSN 0034-9631 (Impreso) ISSN 2154-4794 (Electrónico) 
de los animales con que los identifica, realzando ora su excelsa humanidad ora su bestialidad extrema.

Al leer los retratos de Vargas Vila, y de los modernistas en general, es importante tener en cuenta el alcance que la ética/estética decimonónica atribuía al temperamento en la construcción de la subjetividad; para ellos, la identificación temperamento-obra fue artículo de fe. ${ }^{3}$ El temperamento determinaba el estilo, marcando indeleblemente las obras de escritores y artistas, convirtiéndolas en sinónimos de su persona y personalidad históricas. ${ }^{4}$ Para Vargas Vila, tal correspondencia establece el patrón que rige sus retratos, extendiendo la identificación autor-obra más allá de los artistas que delinea; todos sus retratos describen a sus modelos enmarcados dentro de la órbita de sus obras, sean estas artísticas o políticas. Semejante perspectiva le permite difuminar las fronteras entre el retratado y el entorno, fundiendo ambos a través de símiles y metáforas extendidas, con frecuencia inspirados por el mundo animal.

La variedad de especies animales, además de la multitud de símbolos y características positivas, negativas o mixtas que la tradición popular y artística les ha asignado, provee a Vargas Vila con un rico filón de connotaciones con los que caracteriza, animalizándolos, a una larga lista de personajes a quienes nunca retrata con objetividad, sino a través de la lente politizada de su ideario liberal y valiéndose de un estilo apasionado y panfletario que traiciona su obvia intención promocionista de ofrecerlos a sus lectores como modelos de vida, dignos de imitación o de rechazo. En ningún momento vacila en enjuiciar implacablemente la vida-obra de sus personajes, aplaudiéndola o reprobándola a través de plásticas imágenes tomadas de la naturaleza o del mundo del arte y de la mitología.

El número de animales y su simbolismo de los que Vargas Vila se apropia para delinear a sus personajes es vasto; cubre desde aquellos que son considerados emblemas de majestad, gloria, belleza y fuerza -el león, el águila, el cisne y el toro- hasta los más rastreros e inmundos - las víboras, las hienas, los buitres, las larvas y los gusanospasando por otros más divertidos y grotescos - los simios, los loros, los papagayos y los monos- o más pacíficos y pasivos -la paloma, la tortuga, la gacela y la oveja- u otros, sorprendentes por lo inesperados -los moluscos, las mariposas o las libélulas-o por no pertenecer al mundo cotidiano sino al del arte y de la fantasía -las sirenas, los tritones y los faunos-. Tal variedad de animales y su uso metafórico para caracterizar a los personajes que retrata está presente desde su primera colección, una demoledora

3 Entiendo la evolución del pensamiento y del arte a lo largo del siglo XIX y primera parte del XX según las investigaciones de Morse Peckham, George H. Mead y Frederick Garber, entre otros. Peckham explora en detalle la búsqueda de identidad en el siglo XIX, subrayando la importancia de la asociación estilo-hombre en la estética de románticos y simbolistas, tales como Baudelaire y Rimbaud (234 y ss.), quienes fueron fundamentales en la construcción del ideario modernista; ver Peckam, Beyond 234 y ss.

4 La identificación obra-hombre que estudia Peckham, se origina con George Louis Leclerc, Conde de Buffon (1707-1788), quien al ingresar en la Academia de la Lengua Francesa pronunció su aforística frase "el estilo es el hombre" en su Discurso sobre el estilo.

Revista Iberoamericana, Vol. LXXXI, Núm. 252, Julio-Septiembre 2015, 741-756 ISSN 0034-9631 (Impreso)

ISSN 2154-4794 (Electrónico) 
representación de sus enemigos políticos que titula Los Providenciales, publicada primero en 1892 y después en 1904, cuando la re-titula "los Divinos" y la convierte en parte de Los Divinos y los Humanos, contrastándola con otra serie de retratos de héroes "humanos" que admira. Igual tendencia a retratar a gran parte de sus personajes enfocándolos a través de características animales se mantendría en las siete colecciones que publicaría en los años siguientes: A la hora del crepúsculo, Los Césares de la decadencia, En las cimas, Pretéritas, Sombras de águilas, De sus lises y de sus rosas e Históricas y politicas. ${ }^{5}$

Las estrategias que emplea Vargas Vila para animalizar a sus modelos se mueven a lo largo de una escala que fluctúa entre las elaboradas metáforas y símiles que animalizan sistemáticamente a la persona y la obra del sujeto, y las simples referencias que reducen ambas a una única imagen animal. El retrato de García Moreno (Divinos) y de Léon Bloy (Sombras), por ejemplo, animalizan al sujeto y su entorno de manera metódica, pero el de Hippolyte Taine (Cimas) y el de Cipriano Castro (Hora) tan sólo contienen concisas imágenes que subrayan algún aspecto animal de su persona-obra que Vargas Vila juzga representativa. Notable es también su habilidad para sacar partido a la variedad de acepciones, a veces contradictorias, que la tradición y el arte han impuesto sobre ciertos animales. Éste es el caso cuando elabora rasgos de algunos que como el león, el tigre o el águila pueden ser símbolos tanto de honor y majestad como de saña y crueldad. Los retratos de estos cuatro personajes y los símbolos que la tradición y el arte han impuesto sobre estos tres animales resultan idóneos por lo concisos y representativos para profundizar en algunas de las principales estrategias empleadas por Vargas Vila para animalizar a sus modelos.

El retrato de Gabriel García Moreno (Ecuador, 1821-1875) se encuentra entre los más antiguos de Vargas Vila. Según explica el propio autor, fue durante su primer exilio en las últimas décadas del XIX y viviendo en Curazao, que escribió y publicó este texto en la serie sobre tiranos Los Providenciales, titulada más tarde Los Divinos. ${ }^{6} \mathrm{La}$ historia oficial reconoce los logros y los fracasos de este gobernante, subrayando que fue un político y escritor, quien aunque benefició a su patria con sus reformas, también contribuyó a desestabilizarla, imponiendo su ideario religioso y conservador: "Fomentó

Las fechas de estos libros se refieren a sus primeras ediciones. Cuatro de ellos están conformados por colecciones previas: Pretéritas contiene los retratos de "Los épicos" (1885) junto a otros dos textos políticos y de discursos que titula "De la guerra" (1885), "De la Historia" (1886) y "En la Tribuna" (1887); Los Divinos y los Humanos contiene Los Providenciales y los "Humanos"; Historias y Políticas, Los Divinos y los Humanos y Los Césares de la decadencia; y De sus lises y de sus rosas, En las cimas y A la hora del crepúsculo.

6 Según explica Vargas Vila en 1920, en su "Prefacio a la edición definitiva" a Los Divinos, los retratos de Los Providenciales "fueron unidos luego, a los bocetos de hombres de libertad, que yo había escrito y publicado en New-York en 1894, en mi Revista ilustrada, Hispano-América, y publicados bajo el título de Los Divinos y los Humanos, en París, en el Año de 1903" (10).

Revista Iberoamericana, Vol. LXXXI, Núm. 252, Julio-Septiembre 2015, $741-756$ ISSN 0034-9631 (Impreso)

ISSN 2154-4794 (Electrónico) 
el progreso material del país y desarrolló la educación, pero su política centralizadora y clerical [...] provocó una violenta oposición. M[urió] asesinado" (Larousse). ${ }^{7}$ La estampa que escribe Vargas Vila tan sólo destaca sus fallos: inicia su retrato introduciendo la imagen animal que considera paradigmática de la persona-obra del dictador y en torno a la cual gira el texto, la del búho, ave que aunque por ser el símbolo de Atenas se asocia a la inteligencia, es más conocida en la cultura popular, como el pájaro de la muerte. Esta asociación le permite colocar en primer plano desde el párrafo inicial el mensaje de muerte que representa el dictador así como su carácter tiránico y cruel, para recalcar después su perfidia en el siguiente, asociándolo a varias otras alimañas igualmente peligrosas y repulsivas:

¡Henos aquí en lo más espeso de la sombra!...

García Moreno es el horrible pájaro de la noche; / para perseguir a este tirano búho, hay que bajar con él hasta el fondo del abismo, siguiéndolo en su voloteo vertiginoso en las tinieblas; / la proyección de la figura de este déspota en la historia, es pequeña y deforme: es repugnante como una larva, y venenosa como una víbora; (Divinos 55)

Para Vargas Vila, la obra de García Moreno es su labor de gobernante, y como no podía ser menos dentro de su ideario modernista, está indeleblemente marcada por la misma deformación siniestra que rige su carácter. Lo representa como un búho, pero un búho malévolo, quien después de aniquilar su patria, mantiene su control ayudado por los esbirros de la Iglesia Católica, reprimiendo cualquier tipo de cambio o de libertad ciudadana:

¿cuál fue su historia?

¡ayudado por los jesuitas asaltó el poder, acogotó el Derecho, mató la Libertad, enterró vivo el pueblo del Ecuador, clavó sobre ese sepulcro una negra cruz, y en uno de los brazos de ella, plegó sus alas y clavó sus garras este inmundo búho, y quedó allí, centinela de la muerte, amenazante y fijo, mirando el horizonte [...] (Divinos 57)

La desconfianza del dictador hacia la ciudadanía no es infundada; sabe que existe un ser capaz de derrotarlo, el patriota y escritor Juan Montalvo, su implacable enemigo. ${ }^{8}$

7 La información histórica sobre los retratados la tomo del Pequeño Larousse Ilustrado, del Nuevo Espasa Ilustrado y de la Encyclopedia of Latin America, no porque estos sean una excepcional fuente de información sino porque condensan la significación de cualquier vida-obra permitiendo comparar la visión de Vargas Vila con el juicio que rinde la Historia.

8 En la sección de este mismo libro dedicada a los Humanos, Vargas Vila delinea la estampa de Montalvo, definiéndole como un "libelista sublime" y valiéndose de imágenes paralelas a las usadas en este retrato, presentándole como "el rugido de un pueblo hecho hombre: cantó y rugió, aleteó como el águila y clavó la zarpa como el león” (Divinos 113).

Revista Iberoamericana, Vol. LXXXI, Núm. 252, Julio-Septiembre 2015, 741-756 ISSN 0034-9631 (Impreso)

ISSN 2154-4794 (Electrónico) 
Vargas Vila plasma la lucha de ideas entre estos dos personajes, conservador uno y liberal el otro, como una lidia de aves de presa, el búho y el águila, fatídica la una y admirable la otra: ${ }^{9}$

¡qué duelo tan trágico y tan grande, el de aquel déspota sombrío y aquel talento indignado, el de aquel búho y aquella águila!

el águila bajaba amenazante sobre el siniestro búho, le picoteaba la cabeza hasta hacerle sangre; lo asordaba dándole aletazos tremendos;

graznaba furioso el negro pajarraco, ensayaba picar, pero caía al fin patas arriba, alborotado el sucio plumaje, herido por aquellas alas poderosas, y entonces el águila se levantaba serena, majestuosa, imponente, y se alejaba hasta perderse en las brumas del pálido horizonte;

y, pasaba esa águila proscrita, por América y Europa, llevando en sus alas como jirones de la sombra con que acababa de luchar, llenando de acentos bélicos el espacio, y contando al mundo el martirio de aquel pueblo, crucificado, secuestrado y mutilado en pleno siglo XIX;

jamás tirano alguno fue tan duramente flagelado en vida, por el látigo de un estilo tan viril. (Divinos 57-58) $)^{10}$

Derrotado García Moreno por Montalvo en el campo de las ideas, Vargas Vila pasa a representar su derrota física, es decir, la muerte innoble del tirano, quien cae bajo el puñal del pueblo "ahogándose en sangre," "llorando e implorando la vida" (Divinos 59). Narrada la muerte del opresor, Vargas Vila concluye su semblanza exaltando el triunfo del águila, o sea, de la palabra ardiente de Montalvo, subrayando el papel decisivo que ésta jugó tanto en la destrucción de la vida de García Moreno como en la reprobación eterna a que le ha condenado la historia:

¡llevado así por el genio poderoso de Montalvo, atado a él, ese tirano infeliz atravesará la historia como un nuevo Mazzepa, eternamente desgarrado, y escuchando como aullido formidable en torno suyo, las eternas maldiciones a su nombre! [...] (Divinos 60)

9 El simbolismo del búho, señor de la noche y de la oscuridad, se contrapone, según Cirlot, al del águila, el ave de la luz solar, y confiere a este conflicto entre García Moreno y Montalvo los tintes épicos de una batalla entre las fuerzas del mal y del bien. Vargas Vila emplea este mismo simbolismo en su retrato de Francisco Morazán: “el sol es el encanto de las águilas y el martirio de los búhos” (Divinos 108).

10 La lucha entre estos dos personajes se extiende más allá de la muerte de ambos. En el retrato de Montalvo plasma una imagen paralela subrayando la violenta oposición del dictador y de sus secuaces a que los restos de Montalvo regresaran a Ecuador: "[el ya muerto buitre] no podía picotearle el vientre, pero anhelaba picotear sus huesos; / un día se vio un buque aparecer en el horizonte... / obscura nube de buitres tendió el vuelo, y graznaban y se cernían sobre el navío y aleteaban furiosos; eran los sacerdotes del Ecuador, que salían a cerrar la entrada a la primera gloria Ecuatoriana; / era que volvían a la patria los huesos de Montalvo, y los buitres del catolicismo salieron a su encuentro; / los apóstoles de la mentira, no han perdonado al apóstol de la verdad" (Divinos 118).

Revista Iberoamericana, Vol. LXXXI, Núm. 252, Julio-Septiembre 2015, $741-756$ ISSN 0034-9631 (Impreso) ISSN 2154-4794 (Electrónico) 
El estilo panfletario con que El Divino condena la persona-obra de García Moreno no es en nada distinto del que emplea para delinear su ambiguo retrato del escritor francés Léon Bloy (1846-1917), personaje del que, si por un lado admira su violento estilo libelista, con el que se identifica, por el otro rechaza por su conservadora, y para él humillante, ideología católica. ${ }^{11}$ El subjetivo juicio de Vargas Vila ha sido sostenido por la historia, Espasa lo identifica subrayando sucintamente los dos aspectos que señala el retratista: su ideología católica y su estilo desapacible: "Escritor francés. [...] Católico ferviente, practicó un estilo visionario y agresivo, hacia las figuras más relevantes de su época." Y es precisamente esta contradicción que Vargas Vila percibe entre el libelista y su ideología, lo que determina la ambigüedad con que enjuicia la persona-obra de Bloy; determina además que este sea uno de sus retratos más largos y complejos, y uno en el que emplea una mayor variedad de animales para captar las contradictorias facetas de su conflictiva persona-obra, lo que no obsta para que la figura del león, inscrita en el nombre de pila del personaje histórico que retrata, le mueva a jugar con su imagen haciéndola figurar de manera prominente en su ambigua caracterización del escritor, quien no obstante la fiereza de sus rugidos y las garras de su persona-estilo, dignas de convertirle en "un león del Apocalipsis, arrastrando un carro de fuego, en las soledades del cielo" (Sombras 111), no deja de ser en su persona-ideario un patético "león ciego perdido en una selva", un león que "encoje las garras" para rezar (Sombras 106; 114).

La dualidad con que "El Divino" da inicio a la semblanza de Bloy coloca en primer plano la ambigüedad con que lo retrata. Declara primero que "es bello y consolador, volver los ojos hacia ciertos espíritus sinceros", asegurando que "uno de estos espíritus, es, este enorme y desconcertante León Bloy" (Sombras 101), pero seguidamente contradice que contemplar la persona-obra del escritor pueda ser "bello y consolador", al sembrar la duda en el lector introduciendo una serie de preguntas que cuestionan si se trata de un santo, un apóstol, un energúmeno o un loco. Sin vacilar rechaza los dos primeros, valiéndose de imágenes que asocian a Bloy, y en especial a la Iglesia Católica, con animales inmundos o feroces: de santo dice tener "cierto rencor agreste, $\mathrm{y}$, cierta maldad nativa"; de apóstol "tiene bien poco" o tiene más bien de "un apostolado de servidumbre mental, hecho para ser predicado a una piara, desde el fondo de una celda; / código de cerdos y de monjes; / de Padre de la Iglesia, sí tiene talla; / un Padre de la Iglesia, ejerciendo la pedagogía del Insulto; / una especie de San Bernardo desesperado; feroz como aquel bulldog inverecundo de las perreras monacales" (Sombras 102, énfasis mío). Contrario a este ataque devastador del carácter del Bloy católico, se yergue la exaltación con que defiende la fogosidad de su estilo, ensalzándolo por medio de los perros otra vez, aunque no ya en su previa versión de ferocidad insolente sino en la libertad de

11 La semblanza de Bloy, junto a las de Thomas Carlyle, Ernesto Hello, Pompeyo Gener, Henrik Ibsen y Hermes Anglada, forma parte del volumen Sombras de águilas.

Revista Iberoamericana, Vol. LXXXI, Núm. 252, Julio-Septiembre 2015, 741-756 ISSN 0034-9631 (Impreso)

ISSN 2154-4794 (Electrónico) 
los perros de caza que atacan a su presa; Bloy, dice Vargas Vila, sí tiene de loco y de energúmeno: "sí; / en el grado bastante para ser sublime; / energúmeno glorioso que ha hecho del Dicterio un azote, para herir con él, a todos los que han entrado, o llegan al Templo / del Renombre; / sus odios, como perros, sin trailla, van siempre a caza, de alguna reputación para morderla" (Sombras 103, énfasis mío). ${ }^{12}$

Establecida su admiración por el arte libelista de Bloy, Vargas Vila pasa a destruir el aspecto de la persona-obra del escritor francés que le desagrada: los odios mezquinos que según él le mueven y que marcan su vida-obra con el aura de la mendicidad y la ingratitud, explícitas en el nombre de "Mendigo Ingrato" (Sombras 104) que escogió para sí, y que le fuerzan a vagar sin rumbo en la vida, como un traidor Judas Iscariote que Vargas Vila iguala a un león ciego perdido en la selva, imagen paradójica por la compasión que sugiere:

unos odios, sin medida, que no tienen límites y, no reconocen fronteras; / este MendigoLibelista, no ha tendido nunca la mano, que no haya sido para pedir o para herir; / [...] hace un honor de ser un mendigo, y, sobre todo: un Mendigo Ingrato; / de este Infortunio $\mathrm{y}$, esta Ignominia, hace su bandera; / [...] y, a ese Lema Hiscariotesco, ha ajustado su Vida; / una Vida de Abandono, de Dolor, y, de Miseria, semejante a la de un león ciego perdido en una selva; / y, León Bloy, es, un ciego del Odio (Sombras 104-106)

Al llegar a este punto, Vargas Vila hace un largo aparte en el retrato, interrumpiendo su delineación para narrar su encuentro con el escritor y para elaborar su estilo panfletario. Explica que una vez le vio en un café y rehusó la oferta de que se lo presentaran por miedo a desilusionarse, pero todavía recuerda su figura, y plasma su impresión del personaje bosquejando la ambigua imagen de un tigre-leopardo sosegado:

renuncié a estrechar la zarpa de la fiera, / que hojeaba con ella los libros, lentamente, voluptuosamente, como un tigre, que acariciara las rosas de un rosal; /

sus ojos devoraban las páginas, con sabia avidez; / sus belfos temblaban, repitiendo para Sí Mismo, ciertos párrafos; / su ferocidad dormía, aletargada; / se diría un leopardo en éxtasis (Sombras 108, énfasis mío)

12 En otra sección del retrato contrasta la labor del crítico con la del libelista; niega que Bloy fuese un crítico, profesión que aborrece y a cuyos practicantes califica de crustáceos; insiste en que fue un libelista que gozó aplastando a sus enemigos como un tigre revoltoso: "Bloy, no es un crítico profesional; / esa ciencia de crustáceos venenosos, no es su ciencia; / la deja para los acerebrados de la prensa, para los Abelardos de la pluma, desesperados de su impotencia; / él, es, un Libelista; / y, es como Libelista, que ha ejercido la Crítica; / es como un tigre, que en un momento de su goce, saliendo a un prado ribereño a un lago, se complace en aplastar con su garra, los nínfeos encantadores, y los juncos florecidos, que se miran en las aguas dormidas... / su misión no es tronchar juncos y nínfeos, pero es un placer, de su espíritu destructor; y se lo da" (Sombras 122-123, énfasis mío).

Revista Iberoamericana, Vol. LXXXI, Núm. 252, Julio-Septiembre 2015, 741-756 ISSN 0034-9631 (Impreso) ISSN 2154-4794 (Electrónico) 
Dibujado el físico, Vargas Vila dedica varias páginas a describir el encarnizamiento y el vigor del estilo de Bloy que tanto admira y a destruir su ideología católica que tanto menosprecia, valiéndose otra vez y paradójicamente de alimañas dañinas tanto como de animales nobles para representar su mensaje:

todo es rugiente en Bloy; / todo, hasta la Resignación; / nada hay más agresivo, que su Humildad; / se diría, que se humilla, como una fiera se arrastra; para dar el salto y, herir mejor; / su ternura, es cruel como la de los lobeznos, cuando se prenden al pezón materno; devoran en vez de acariciar; / [...] así caracolea Bloy, en un Circo de elipsis, de apóstrofes y de metáforas, todas centellantes, como si las incendiara con tocarlas; / es un león del Apocalipsis, arrastrando un carro de fuego, en las soledades del cielo; (Sombras 110-111, énfasis mío)

La fuerza y la pasión que Vargas Vila descubre en el estilo de Bloy es algo que decididamente admira, pero su entusiasmo no se extiende hasta incluir la ideología católica que ese estilo defiende. Sus ataques contra dicha ideología son tan contundentes como las alabanzas que prodiga a su estilo, y se dirigen no sólo hacia Bloy sino en especial hacia los grandes Padres defensores de la Iglesia, a quienes Vargas Vila animaliza brutalmente, salvaguardando siempre la persona-estilo de Bloy por medio de una imagen más ambivalente, la más agradable y menos amenazadora del colérico león:

el catolicismo virulento de Bloy, es, el más lógico de todos los que yo he conocido, porque es cruel, absurdo y malo, como el alma del Catolicismo; / su intemperancia, su inverecundia, su odio a la Libertad, católicos son; / su Fe, no pudiendo ser una Idea, hecha Crimen, como en los inquisidores, ha querido ser un Crimen, hecho Idea, como en los teólogos; / pero, él, no tiene el corazón de hiena, de un Ignacio de Loyola, ni el testuz bovino de aquel cornúpeto enfurecido que / fue Tomás el de Aquino; / sus cóleras, si no son nobles, son grandes: cóleras de león; (Sombras 112-113, énfasis mío)

Las facetas del león colérico y del tigre-pantera, pensador y libelista despiadado, no son las únicas que Vargas Vila delinea de Bloy. La ambigüedad con que percibe su persona-obra le lleva a elaborar también la más patética imagen del Bloy esposo y padre de familia, viviendo en la pobreza, mendigando el pan de cada día. No obstante la simpatía hacia esta faceta familiar, su retrato de Bloy y de su esposa sumidos en el rito católico resulta ambigua de nuevo; por un lado, la representa a través del positivo simbolismo animal del león y de la paloma, el coraje y la paz, pero por el otro, lo socava cuando transforma al amante león en un macizo paquidermo, provocando un retorcimiento en la imagen que introduce una profunda nota de sarcasmo:

[Bloy y su mujer] entran a la Soledad penumbrosa de las basílicas y, se absorven en la Oración; / la paloma abre las alas y, el león encoje las garras; / y, oran; / y, la paloma

Revista Iberoamericana, Vol. LXXXI, Núm. 252, Julio-Septiembre 2015, 741-756 
vela, sobre el león que reza; / esfolian las páginas de un libro de devoción, y cantan juntos, como dos cristianos primitivos en el fondo de una catacumba; / como todos los animales de fuerza, Bloy es pudoroso en su Amor; tiene el pudor de un paquidermo (Sombras 114, énfasis mío)

Pese a la ironía de esta representación del Bloy-esposo, su retrato del Bloy-padre de familia está exento de ella; su uso del pelícano, símbolo de auto-sacrificio y por extensión de la muerte de Cristo en la cruz, imparte un aura de mártir a la figura del libelista, cuya muerte metafórica, con la mansedumbre de unáguila agonizante, despierta la compasión del lector:

la Miseria, le arranca los más bellos rugidos, y, el cuello hercúleo, se hace lírico, cuando pasa por él el tropel de los sollozos; / en sus noches sin pan y, sin abrigo, se muerde el corazón, y, lo da en pedazos a sus hijos, como un pelícano de esplendor y de magnificencia, dándose en holocausto, sobre la cruz de sus alas; / con una mansedumbre salvaje de águila agonizante (Sombras 117, énfasis mío)

La ambigüedad de la representación de la persona-obra de León Bloy, efecto de la admiración de Vargas Vila por su iracundo estilo panfletario, ocasiona que sea precisamente dicho estilo el que le dicte la última estampa que deja con el lector, poniendo fin a su polifacético retrato con un exaltado panegírico del Mendigo Ingrato, del Libelista, que la pluma de El Divino transmuta en "escritor glorioso":

y, este Escritor glorioso, es gloria de Francia; de Francia, que es la Gloria del Mundo; / y, este Hombre, no cede, no se rinde, no capitula; / continúa en combatir, es decir, en insultar; [...] nadie, ni Luzbel fué más grande en su Infortunio... / viéndolo pasar coronado de espinas, la Admiración del Mundo, debe inclinarse para decir: / Ecce Homo / he aquí el Hombre del Dolor... / el Invendible... / el Peregrino de lo Absoluto... / ¡Salve al Mendigo Ingrato! / ¡Salve!... (Sombras 131-132, énfasis en el original)

Los retratos de García Moreno y de Bloy muestran dos de las estrategias empleadas por Vargas Vila para animalizar a sus modelos. El lector conoce al primero a través de una serie de asociaciones con las características de un mismo animal, el búho, mientras que para conocer al segundo se ve obligado a asociarlo no sólo a uno sino a varios animales, entre ellos, perro-de-caza, león ciego, lobezno, tigre-pantera, león del Apocalipsis, león, paquidermo, pelícano, águila agonizante, característico cada uno de ellos de diferentes aspectos de la persona-obra de Bloy que Vargas Vila desea subrayar. Los retratos de Hippolyte Taine y de Cipriano Castro que estudio a continuación ejemplifican otras dos maneras alternativas de usar la animalización para plasmar la esencia de una persona-obra.

El retrato del historiador francés Hippolyte Taine (1828-1893) forma parte de En las cimas, una colección de ocho semblanzas de intelectuales que Vargas Vila representa no

Revista Iberoamericana, Vol. LXXXI, Núm. 252, Julio-Septiembre 2015, $741-756$ ISSN 0034-9631 (Impreso)

ISSN 2154-4794 (Electrónico) 
desde la totalidad de su persona-obra sino centrándose en un sólo aspecto de la misma, que señala claramente por medio de un subtítulo. ${ }^{13}$ De hecho, estas semblanzas parecen haber sido pensadas como reseñas o comentarios a libros escritos por o sobre los autores que Vargas Vila retrata. La de este famoso escritor se titula "Hippolyte Taine. Historiador", un retrato en que El Divino no celebra y elabora la ideología del conservador Taine sino que se fundamenta en un libro escrito por un tal Monsieur Audelart atacando un importante tratado del historiador: Orígenes de la Francia contemporánea (1876). El enfoque de este retrato es de interés adicional por lo que revela del juicio de Vargas Vila sobre su propia persona-obra. ${ }^{14}$ Como en el caso de Bloy, Taine es católico y reaccionario, pero contrario a él, no es un ardiente libelista sino un crítico desapasionado de la historia, y los críticos resultan ser uno de los grandes irritantes contra los que Vargas Vila esgrime su pluma. No es sorprendente pues que dedique más de la mitad de este texto a atacar a los críticos, con quienes desde el inicio de su semblanza asocia a Taine para destruir su reputación: "Nada detiene, el cortejo extasiado de los admiradores de Taine; / aquellos peregrinos del Santo Sepulcro, guardan las cenizas, y, el pensamiento del Maestro, con una candorosidad y un fervor fanáticos, que llegarían a imponer respeto, si no pasasen a diario las fronteras del ridículo; / [...] yo, no conozco un crítico, es decir, un mediocre, que no tenga una pasión desmesurada de respeto y de veneración, por aquel genízaro de los sofistas" (Cimas 39-40). Providencialmente, añade "El Divino", Monsieur Audelart ha escrito un libro en que prueba la deslealtad y la falta de escrúpulos con que Taine calumnió a los hombres de la Revolución francesa sólo para avanzar su ideología, o sea, "por el placer servil, de contentar a los partidos reaccionarios, cuyos sufragios codiciaba" (Cimas 41). Opinión que él comparte y que le sirve para destruir la fama de historiador de Taine, explicando primero que no puede serlo "precisamente porque es un crítico, o mejor, un difamador de la historia" (Cimas 41), y resumiendo después los juicios que Taine expresa sobre la Revolución en la repulsiva imagen de un perro sanguinario: "fué incapaz de hacer justicia a la Revolución, porque fué incapaz de comprenderla; aullando en torno a los cadalsos, tiene el aspecto siniestro de un perro de verdugo enloquecido al olor de la sangre" (Cimas 51, énfasis mío).

Para Vargas Vila, la bajeza de pensamiento de Taine, es decir, la mezquindad de su carácter, provoca la mediocridad de su estilo, por lo que en términos de su pensamiento ético/estético modernista, su obra y su persona son equivalentes en su vulgaridad, y "El Divino" las funde convincentemente en un sintético retrato de su persona-estilo, valiéndose de imágenes de animales que, como el genérico paquidermo y los más

${ }^{13}$ Filósofo, historiador y crítico, Taine es conocido principalmente como un influyente teórico del naturalismo o, según lo expresa el Larousse, por su intento de "aplicar el método de las ciencias naturales a las producciones más diversas del espíritu humano".

${ }^{14}$ En un ensayo titulado "El Divino en sus retratos literarios", estudio estos retratos como un autorretrato del temperamento, los gustos y las inquinas de Vargas Vila.

Revista Iberoamericana, Vo1. LXXXI, Núm. 252, Julio-Septiembre 2015, 741-756 ISSN 0034-9631 (Impreso)

ISSN 2154-4794 (Electrónico) 
específicos hipopótamo y elefante, subrayan su pesadez y falta de gracia y agilidad, acentuadas por la falta de alas y de elevación de su obra-alma que inscribe en las dos citas que siguen, si bien en el caso de la segunda no puede menos que hacer concesiones al hermoso estilo de Taine:

su estilo sin alas, pero lleno de solidez brillante, semeja el dorso grasoso de un hipopótamo, visto bajo el sol; / y, él tiene en su espíritu, la misma pesantez del paquidermo; / es en todos sentidos, una alma refractaria al vuelo; / su carrera de elefante en furia, lo fatiga y no lo eleva; pisa los acontecimientos, no los ve; tritura lo que debería juzgar; y hace una enorme diatriba, de lo que un hombre de más talento, habría hecho, una bella obra (Cimas 54-55; énfasis añadido)

cuando quiere ser irónico, es de una brutalidad espesa, y de un bufo tan vulgarmente grotesco, que parece la danza de un oso ebrio, martirizado por la fusta de un gitano; / todo en él, es paquidérmico; / y cubierto por las galas suntuosas de su estilo, semeja el elefante de un Rajah, enjaezado para una fiesta (Cimas 64, énfasis mío)

En general, el retrato de Taine ilustra el uso de la animalización para expresar la negatividad de Vargas Vila hacia la vida-obra de un hombre cuyo ideario conservador y cuya objetiva mediocridad de estilo desprecia; el de Cipriano Castro (Venezuela, 18581924) ofrece una cuarta manera de animalizar, sintética y humorísticamente en este caso, para ilustrar la incompetencia de su carácter y de su gobierno. Castro, general y político, se hizo con el poder en un golpe militar en 1899, gobernó de manera dictatorial y fue depuesto por Vicente Gómez, su primer ministro, aprovechando un momento en que minado por la enfermedad había viajado a Europa en busca de salud. La incapacidad de Castro es de tal magnitud que según la Encyclopedia of Latin America gobernó con un estilo y un verbo tan maléficos que es reconocido universalmente como uno de los más corruptos, ineficientes e irresponsables dictadores latinoamericanos. Vargas Vila coincide con esta opinión, retratándole durante su exilio en París y burlándose de su recién adquirido y vacío título de Poeta ("¡Pobres poetas de América! / no ganan para sustos; / cuándo no les sale un enemigo furioso, como el pacífico e inenarrable General Uribe Uribe, les sale, ¡un rival terrible, como el no menos heróico General Cipriano Castro" [Hora 175]). Si de nuevo extendemos el concepto de que su temperamento es equivalente a su poesía, a que su temperamento equivale a su gobierno de Venezuela, se hace evidente que no es sólo el vacío de su producción poética lo que condena Vargas Vila sino que el vacío se refiere también a la incompetencia de su gobierno, indicando que nada aportó ni a la poesía ni a la nación:

yo, no me fatigaré de excitar la juventud, a que lea esos dos poetas; es verdad que Castro, no ha escrito nada, dando con eso una prueba de superioridad sobre el otro [Gonzalo Picón Febres, padre]; después de leído éste, se verá que ha imitado servilmente y ultrajantemente a Castro; no ha escrito tampoco nada (Hora 181, énfasis mío)

Revista Iberoamericana, Vol. LXXXI, Núm. 252, Julio-Septiembre 2015, $741-756$ ISSN 0034-9631 (Impreso) ISSN 2154-4794 (Electrónico) 
Dada la irrelevancia de la persona-obra de Castro, vale decir, el vacío de su obra poética y política, no es de sorprender que cuando Vargas Vila trazó su retrato, lo hiciera en términos que lo colocan en una dimensión de irrealidad y fantasía, transformándole en un mítico Pegaso, animalizándole burlona y poéticamente, calificándole de bruto en cuatro patas, pero sin beneficiarle asignándole algún tipo de connotación negativa o positiva que un animal real pudiera haberle prestado, humanizando la incongruencia de su persona-obra o imponiendo un valor determinado a sus acciones: "desterrado del Capitolio, Ciprianito aspira a trepar al Helicón, siquiera sea en calidad de Pegaso; todas sus cuatro patas se estremecen de júbilo a esta sola idea" (Hora 176, énfasis mío).

La habilidad de Vargas Vila para establecer paralelismos entre la persona-obra humana y la animal es evidente en estos cuatro retratos, pero por estar limitado cada uno de ellos a la estampa de un solo individuo ninguno es capaz de reflejar en toda su extensión la imaginación con que el autor se apropia del mundo animal, usando para sus propios fines las connotaciones y símbolos que el arte, la literatura y la cultura popular le han adjudicado. Para analizar este aspecto de la caracterización de sus retratos me valgo de la figura de tres animales paradigmáticos de la cultura del mundo occidental, el león, el tigre y el águila. En el caso del león, Juan Eduardo Cirlot señala la variedad de acepciones que se relacionan con el Rey de la Selva; su prestigio como dios-sol en las culturas primitivas, añade, persiste en el simbolismo cristiano, en el que se le asocia al evangelista San Marcos; su estampa de rey de las bestias se representa como la oposición terrena del águila, reina de los cielos; es el amo y señor, el dueño de la fuerza y del principio masculino; la virilidad; en su versión de león domado connota lo opuesto.

La frecuencia del uso del león por Vargas Vila es segunda a la del águila, su símbolo preferido, pero la riqueza de connotaciones que le atribuye no es menos notable. Su simbología sigue de cerca la que describe Cirlot, usando el león para celebrar las acciones gloriosas o la palabra ardiente de sus héroes, tal cuando describe a Ricardo Gaitán Obeso como "un león de Numidia" (Pretéritas 69), el éxito de Víctor Hugo como "la marcha victoriosa del León" (Lises 119), la "melena de león en furia" de Eloy Alfaro (Históricas 125), los "rugidos de león" de la elocuencia de Diógenes Arrieta (Divinos 159), y las "mandíbulas de león" de los apotegmas de Nietzsche (Lises 107). Pero también lo usa para despertar la compasión y devaluar el mérito de algo o de alguien: Bloy es el "león ciego perdido en una selva" y el león que "encoje sus garras" (Sombras 106; 114), el Páez político es un "viejo león hipnotizado" (Divinos 151), Joaquín Crespo vencido es un "león encadenado" (Divinos 154) y el arte católico del Renacimiento es parangonado a "leones intesticulados" (Sombras 81).

$\mathrm{Al}$ igual que la figura del león le presta sus características reales y atribuidas para delinear a muchos de sus personajes, el tigre también le presta las suyas, ayudándole a precisar otros temperamentos, posturas y estilos. El tigre, según Cirlot, además de estar asociado a Dionisio, dios del vino, a los excesos y el éxtasis, simboliza la ferocidad y la crueldad pero también fuerza y valor. En los retratos de Vargas Vila puede ser una

Revista Iberoamericana, Vol. LXXXI, Núm. 252, Julio-Septiembre 2015, 741-756 ISSN 0034-9631 (Impreso)

ISSN 2154-4794 (Electrónico) 
imagen positiva usándolo, por ejemplo, para describir el dinamismo del discurso de Nietzsche, "un tigre dando saltos en un zarzal incendiado" (Lises 107); también puede describir varios aspectos de una misma vida-obra, como en la semblanza de Bloy, en la que aparece tres veces, una para retratar su físico, hojeando un libro "lentamente, voluptuosamente, como un tigre, que acariciara las rosas de un rosal" (Sombras 108, énfasis mío), otra, para describir su vida-obra sometida al control de la Iglesia Católica: "su Vida, es, un rugido enorme, de tigre prisionero debajo de un altar" (Sombras 116, énfasis mío), y una tercera, para ilustrar el devastador estilo libelista con que se deleita destruyendo a otros: "es como un tigre, que en un momento de su goce, saliendo a un prado ribereño a un lago, se complace en aplastar con su garra, los nínfeos encantadores" (Sombras 123, énfasis mío). No obstante estas imágenes afables, la figura feroz del tigre es la que con mayor frecuencia emplea Vargas Vila; con ella describe la tiranía y a sus tiranos. En el retrato de Ernesto Hello habla en términos generales; afirma que "todo Tirano, es como un tigre ciego, que camina en la selva al olor de la sangre" (Sombras 60), y advierte no enviar a los tiranos al exilio, acción que iguala a "envenenar la atmósfera de un prado virgen, arrojando en él, el cadáver de un tigre" (Sombras 69), en vez, asegura, los tiranos deben morir: "César proscripto, es César mártir... un tigre romantizado por la leyenda, es más peligroso, que un tigre coronado por los líquenes de la selva; sólo muertos, un tigre y, un tirano, dejan de ser peligrosos" (Sombras 69). El tigre es la imagen que describe al déspota Rafael Reyes, cuya presencia se predice en el retrato de Marroquín "y, el tigre entra en escena [...]” (Césares 101), en Históricas explica que Reyes, el tirano en ciernes, se refugia en la selva que lo llama, y va hacia ella "como un cachorro de tigre, hambriento de morder el pezón que ha de nutrirle" (79), para emerger con furia años más tarde "como un tigre salido de la montaña a la llanura, sintió el deslumbramiento del sol de la Civilización [...] la sangre se escapaba a torrentes de las venas de la nación [...] y Reyes se puso a chupar esa sangre con delicia, como en una ubre ubérrima [...] y, las mandíbulas del tigre se fatigaron devorando hombres" (Históricas 82). Tigre es también Rafael Núñez, quien vive "en plena selva, como un tigre" (Lises 185) y Mariano Melgarejo, "cruel como un tigre" (Divinos 51), y el argentino Juan Manuel Rosas, a quien Vargas Vila atribuye "la espantosa faz del tigre" y quien en el destierro paseaba impaciente a orillas del mar "como un tigre en los juncales de un pantano" (Divinos 49; 50).

La habilidad con que Vargas Vila delinea diferentes aspectos de la vida, persona y obra de muchos de sus personajes históricos manipulando los significados contradictorios asociados a las imágenes del león y del tigre es innegable, pero donde verdaderamente brilla su inventiva es al desplegar las múltiples atribuciones simbólicas deláguila. Metáfora de altura y espiritualidad en general, el águila es símbolo, según Cirlot, del día y de la luz solar, que se opone al búho, el espíritu de la noche y de la oscuridad; es el ave de Júpiter y de la majestad divina, asociada al poder y a la guerra; su fuerza y dignidad en

Revista Iberoamericana, Vol. LXXXI, Núm. 252, Julio-Septiembre 2015, $741-756$ ISSN 0034-9631 (Impreso)

ISSN 2154-4794 (Electrónico) 
el aire la iguala al león en la tierra. No obstante, en el mundo cotidiano, el majestuoso vuelo del águila no merma el terror de sus víctimas indefensas. Vargas Vila emplea esta última imagen realista de rareza, y siempre de manera insólita; en cierta ocasión lo hace para defender a Nietzsche, acusado de antipático: “¿creéis que las aves de corral encuentran simpática el águila, cuando vuela sobre ellas con las garras recogidas" (Lises 112), en otra, para plasmar su desagrado hacia los genios que someten su pluma a un dictador: "ahí, está para probarlo, el genio claudicante de Goethe [...] águila convertida en ave de corral" (Sombras 57); y en una tercera, para describir el ejército de Joaquín Crespo cayendo "como una bandada de águilas que azotara la llanura" (Divinos 152).

El águila como símbolo degradado que se observa en estos ejemplos no es la norma en los retratos de Vargas Vila, aunque sí hay dos casos en que el tirano se asocia con el águila como ave de rapiña, afirmándose en uno que Rafael Reyes no tiene alas sino garras (Históricas 71), y convirtiendo al dictador Rodríguez de Francia en el otro, en "un aguilucho salvaje en la grieta de una roca, inmóvil la roja pupila, crispadas las garras, y erizado el plumaje" (Divinos 43). Con todo, lo que priva en ellos es que el águila sirva como símbolo noble, enalteciendo y celebrando a sus héroes. Así, Daniel Hernández fue "el águila de la revolución, [que] coronaba la cima de los Andes" (Pretéritas 85), Pimentel Coronel "libre fue, como una águila" (Hora 54), Hello un "águila marina" (Sombras 85), Francisco Morazán el "águila liberal herida" (Divinos 102), Rafael Núñez "un águila marina vencida por las tormentas" (Divinos 62), Léon Bloy "un águila agonizante" (Sombras 117) y Gaitán Obeso un águila que "herida en medio de su vuelo, plegó las alas y fue a morir junto al mar" (Pretéritas 74). La identificación persona-estilo permite que la majestad del águila sirva también para designar la obra, condenándola unas veces y exaltándola otras: la obra crítica de Bloy es "fiemo de águila, que ha servido de abono" (Sombras 122); el estilo de Montalvo por el contrario, "aleteó como el águila y clavó la garra como el león", destruyendo a los tiranos al igual que "levantan las águilas a las serpientes en el pico y en las garras" (Divinos 113; 117), y las frases ardientes de la oratoria de Jorge Isaacs salen de su boca "con el rumor alarmante de una bandada de águilas marinas que se escapan del nidar" (Divinos 173).

Las estrategias de animalización que Vargas Vila emplea en estos cuatro retratos y la habilidad con que se apropia del simbolismo de estos tres animales para caracterizar a sus personajes representan tan sólo una pequeña cala en el arte con que escribe semblanzas de aquellas personas cuyas ideas admira o detesta. Sus retratos, enfocados siempre desde la subjetividad panfletaria de su ideario liberal, le llevan a exagerar los tintes, construyendo semblanzas que, si por un lado se atienen en lo esencial a la integridad histórica de la vida-obra de sus modelos - manteniendo el pacto biográfico que todo lector espera de un retrato personal-, por el otro, su subjetividad enardecida les coloca más cerca del libelo y de la caricatura que de la objetiva impasibilidad de un retrato. Empero, es precisamente su apasionamiento, su exageración, lo que anima a

Revista Iberoamericana, Vol. LXXXI, Núm. 252, Julio-Septiembre 2015, 741-756 ISSN 0034-9631 (Impreso)

ISSN 2154-4794 (Electrónico) 
sus personajes, lo que les infunde un color y una vida que no logran darle los inocuos resúmenes de la historia. Contrario a ella, los retratos de "El Divino" Vargas Vila entregan a sus insólitos modelos -sus hombres y otras alimañas los he llamado en el título-clavados en posturas extremas, como los vistosos insectos de un coleccionista, exhibiendo ostentosamente en sus vicios y virtudes las flaquezas y las grandezas de la compleja vivencia humana.

\section{OBRAS CITADAS}

Cirlot, Juan Eduardo. A Dictionary of Symbols. New York: Philosophical Library, 1962. Delpar, Helen, ed. Encyclopedia of Latin America. New York: MacGraw-Hill, 1974. Garber, Frederick. The Autonomy of the Self from Richardson to Huysman. Princeton: Princeton UP, 1982.

Mead, George H. Movements of Thought in the Nineteenth Century. Chicago: U of Chicago P, 1962.

Nuevo Espasa Ilustrado. Diccionario Enciclopédico. Madrid: Espasa, 2003.

Peckham, Morse. Beyond the Tragic Vision. The Quest for Identity in the Nineteenth Century. New York: George Braziller, 1962.

Pequeño Larousse Ilustrado. $8^{\text {a }}$ tirada. París: Ediciones Larousse, 1972.

Salgado, María A. "El Divino en sus retratos literarios". Hispanic Journal 34/2 (2013): 115-131.

Teofrasto. Selección de los caracteres. Madrid: [s.n.], 1951.

Triviño Anzola, Consuelo. "Vargas Vila o el arte de injuriar". Los Césares de la decadencia.

José María Vargas Vila. Santa Fe de Bogotá: Planeta, 1995. 9-24.

Vargas Vila, José María. A la hora del crepúsculo. 1900? Barcelona: Casa Editorial Maucci, 1916.

De sus lises y de sus rosas. 1920. Barcelona: Ramón Sopena, 1931.

En las cimas. Barcelona: Casa Editorial Maucci, 1916. Históricas y políticas. Barcelona: Ramón Sopena, 1930?

Los Césares de la decadencia. 1907. Ramón Sopena, 1930.

Los Divinos y los Humanos. 1904. Juan Carlos González Espitia, ed. y epílogo; Consuelo Triviño Anzola, intro. y pról. Santafé de Bogotá: Panamericana Editorial, 1998.

Pretéritas. Barcelona: Ramón Sopena, 1921.

Sombras de águilas. 1916? Juan Carlos González Espitia, ed. y epílogo; Consuelo

Triviño Anzola, intro. y pról. Santafé de Bogotá: Panamericana Editorial, 1998.

Revista Iberoamericana, Vol. LXXXI, Núm. 252, Julio-Septiembre 2015, 741-756 ISSN 0034-9631 (Impreso)

ISSN 2154-4794 (Electrónico) 